\title{
Polycyclic Aromatic Hydrocarbons (PAHs) and Estrogenic Compounds in Experimental Flue Gas Streams
}

\author{
W. Muthumbi, P. De Boever, J. G. Pieters, S. Siciliano, W. D'Hooge, and W. Verstraete*
}

\begin{abstract}
The importance of combustion processes as a source of substances with estrogenic activity in the environment was investigated. Wood (nontreated and treated with wood preservatives), barbecue charcoal, meat, and kitchen waste were combusted in a laboratory-scale incinerator. Flue gas emissions (particulates and gaseous pollutants) were trapped in polyurethane foam cartridges. The cartridges were subjected to Soxhlet extraction and part of the extracts redissolved in dimethylsulfoxide (DMSO) for analyses of estrogenic activity by means of the yeast-based human estrogen receptor (hER) bioassay. A synthetic estrogen, 17- $\alpha$-ethinylestradiol (EE2), was used as the reference estrogenic compound. Part of the extracts was analyzed for the 16 USEPA priority polycyclic aromatic hydrocarbons (PAHs). Estrogenic compounds in the flue gas (wood) were as high as $234 \pm 25 \mathrm{ng} \mathrm{m}^{-3}$ EE2 equivalent compared with 27 to $81 \mathrm{ng} \mathrm{m}^{-3} E E 2$ equivalent in flue gas from combustion of barbecue charcoal. Concentrations of polycyclic aromatic hydrocarbons in both flue gas streams were in the range of $21000 \pm 2000$ and $240 \pm 110 \mathrm{ng} \mathrm{m}^{-3}$, respectively. In general, the concentrations of EE2 equivalent in the flue gas samples were at least a factor of 1000 lower than total PAH concentration. The EE2 levels were not related to the concentration of PAHs in any flue gas sample.
\end{abstract}

$\mathrm{F}$ LUE GAS EMISSIONS from incomplete combustion processes contain a complex mixture of organic micropollutants (Davies et al., 1976; Pimenta et al., 2000). For example, in flue gases from combustion of wood chips, 142 different compounds, which included aliphatic hydrocarbons, PAHs, carboxylic acids, alcohols, ketones, phenols, and steroids, were isolated and characterized (Simoneit et al., 2001). Incomplete combustion of wood produces estrogenic compounds (Muthumbi et al., 2002). Incomplete combustion processes occur in uncontrolled burning of domestic waste or animal carcasses and domestic heating systems operated on biomass fuels such as bark, sawdust, wood chips, charcoal, straw, wholeplant cereals, or hay (Obernberger, 1998; Launhardt and Thoma, 2000; Gullett et al., 2001). Polycyclic aromatic hydrocarbons are one of the largest groups of compounds of organic micropollutants in flue gas emissions (Simoneit et al., 2001) and some PAHs are suspected to have estrogenic activity, especially in their hydroxylated form (Clemons et al., 1998; Charles et al., 2000). Exposure of humans to estrogenic compounds in the environment may be responsible for the apparent increase in hormone-dependent cancers of breast, ovaries, endome-

W. Muthumbi, P. DeBoever, S. Siciliano, and W. Verstraete, Laboratory of Microbial Ecology and Technology, (LabMET), Faculty of Agricultural and Applied Biological Sciences, Ghent University, Coupure Links 653, 9000 Ghent, Belgium. J.G. Pieters, Biosystems Engineering, Ghent University, Coupure Links 653, 9000 Ghent, Belgium. W. D'Hooge, Endocrinology, Ghent University Hospital, De Pintelaan 185, 9000 Ghent, Belgium. Received 30 Nov. 2001. *Corresponding author (Willy.Verstraete@rug.ac.be).

Published in J. Environ. Qual. 32:417-422 (2003). trium, thyroid, testes, and prostate as well as a variety of abnormal physiological and morphological effects in higher life forms (Arnold et al., 1996; Gillesby and Zacharewski, 1998; Guillette et al., 1994, 1996; McLachlan et al., 1982).

Several in vitro bioassays of different complexity have been used to screen for presence of estrogenic compounds in environmental matrices (Zacharewski, 1997). In the past we have used a yeast-based human estrogen receptor (hER) in vitro bioassay, described and extensively validated previously by Routledge and Sumpter (1996) and optimized by De Boever et al. (2001) for the measurement of estrogenic activity in flue gas extracts. Large amounts of PAHs in air are emitted from combustion operations. Estrogenic compounds have a remarkably wide variety of chemical structures whose molecular details are rather pervasive (Katzenellenbogen, 1995). Principally, it can be observed that most natural estrogenic compounds posses a structural motif consisting of at least two PAH rings. As such, it was of interest to investigate whether the presence of estrogenic compounds in flue gas streams was related to the $16 \mathrm{PAHs}$ listed as priority pollutants by the USEPA (McCready et al., 2000).

\section{MATERIALS AND METHODS}

\section{Flue Gas Generation and Sampling}

Flue gas samples were generated by combustion of three distinct samples of $300 \mathrm{~g}$ wood chips, barbecue charcoal, kitchen waste, or meat. One set of wood samples was subjected to burning without additional treatment. A second set of wood samples was treated by submersion $(12 \mathrm{~h})$ in paraffin oils containing 3\% copper naphthenate wood preservative, and a third set of wood samples was treated by submersion in paraffin oils containing 3\% copper naphthenate wood preservative and pentachlorophenol $\left(3 \mathrm{~g} \mathrm{~L}^{-1}\right)$. The treated sets of wood samples were allowed to dry before combustion. Copper naphthenate and pentachlorophenol wood preservatives were used to provide worst-case burning scenarios, possibly enhancing the formation of polychlorinated biphenyls (PCBs), polychlorinated dibenzo dioxins (PCDDs), and polychlorinated dibenzo furans (PCDFs). Copper naphthenate and pentachlorophenol have been used to enhance the formation of chlorinated organic compounds in experimental combustion processes (Gullett et al., 2000; Stieglitz and Vogg, 1987).

The combustion was performed in a 1-m-long refractory brick-lined electrical oven divided into two compartments. The temperature in both combustion chambers was chosen to approximate scenarios in uncontrolled burning of wood, charcoal, dead animal carcasses, and backyard waste. The first compartment was heated to $1000^{\circ} \mathrm{C}$ by means of a $3-\mathrm{kW}$ electri-

Abbreviations: DMSO, dimethylsulfoxide; EC50, effective concentration to cause $50 \%$ of the mean maximum estrogenic response; EE2, $17-\alpha$-ethinylestradiol; PAH, polycyclic aromatic hydrocarbon. 
cal coil, while the second was not. Temperature at the exit of the secondary combustion chamber varied between 100 and $320^{\circ} \mathrm{C}$. Using a suction pump, flue gas samples were led through an air-cooled stainless steel tube (0.5-in [12.7-mm] i.d.) fitted at the back of the secondary combustion chamber into a Supelco ORBO 2000 polyurethane foam (PUF) adsorption cartridge (Sigma-Aldrich, Bornem, Belgium) to trap the particles as well as to sorb the PAHs and other organic pollutants. Before the start of the combustion experiments and in between each set of subsamples, the sampling pipes $(0.5$-in $[12.7-\mathrm{mm}]$ stainless steel tubes) were dismounted and cleaned with concentrated sulfuric acid containing potassium dichromate (40 g $\mathrm{L}^{-1}$ ) to oxidize organic compounds attached on the walls and rinsed with water several times. In addition, both compartments of the oven were heated to $800^{\circ} \mathrm{C}$ for $4 \mathrm{~h}$ to oxidize traces of organic compounds and hence eliminate memory effects.

\section{Recovery of the Organic Micropollutants}

Polyurethane foam adsorption cartridges were Soxhlet extracted with a $160-\mathrm{mL}(3: 1 \mathrm{v} / \mathrm{v})$ mixture of $n$-hexane and acetone (high performance liquid chromatography [HPLC] grade; Merck Eurolab, Leuven, Belgium) for $24 \mathrm{~h}$. In all cases, the final volume of the Soxhlet extract was on average 135 and $50 \mathrm{~mL}$. Each of these extracts were evaporated in a rotorvap apparatus under low pressure and the organic compounds redissolved in an equal volume of dimethylsulfoxide (DMSO) (99.5\%; Sigma-Aldrich) for performing the estrogen screen bioassay. The remainder of the extract was used for the analyses of the 16 standard PAHs.

\section{Yeast Estrogen Screen Bioassay}

About $125 \mu \mathrm{L}$ of frozen yeast cell culture $\left(-70^{\circ} \mathrm{C}\right)$ was thawed and added to $50 \mathrm{~mL}$ minimal growth medium supplemented with essential vitamins, amino acids, and $2 \%$ glucose as in Routledge and Sumpter (1996). The culture was incubated at $28^{\circ} \mathrm{C}$ for $2 \mathrm{~d}$ to attain an optical density of 1.0 at $630 \mathrm{~nm}$. The culture was again subcultured for $24 \mathrm{~h}$ to provide yeast cells in the exponential growth phase. A fresh assay medium was then prepared by addition of $0.5 \mathrm{~mL}$ of the second-generation yeast culture to $50 \mathrm{~mL}$ of growth medium.

Eight $(100-\mu \mathrm{L})$ aliquots of each flue gas extract in DMSO were placed in the first column of a 96-well polystyrene multiwell plate (Merck Eurolab) and serially diluted to $2^{10}$. Alongside, a stock solution (148 $\left.200 \mathrm{ng} \mathrm{L}^{-1}\right)$ of 17 - $\alpha$-ethynylestradiol (EE2) was serially diluted to give EE2 concentration in the range of 148200 to $144.7 \mathrm{ng} \mathrm{L}^{-1}$. Fresh assay medium $(245 \mu \mathrm{L})$ was added to a 96-well multiwell plate and EE2 dissolved in DMSO $(5 \mu \mathrm{L})$ was added to attain a final concentration range of 2.89 to $2964 \mathrm{ng} \mathrm{L}^{-1}$ in the wells at $\%$ DMSO content. Dilution series $\left(2^{0}-2^{10}\right)$ of the flue gas sample extracts in DMSO solvent were analyzed for estrogenic activity in a similar manner. All the plates were wrapped in a parafilm foil along the edges to minimize evaporation and incubated at $32^{\circ} \mathrm{C}$ for $72 \mathrm{~h}$

For each sample, the contents of each well were then mixed by means of pipetting up and down several times with a multipipette and $150 \mu \mathrm{L}$ were transferred into the respective wells of a separate 96-well multiwell plate. Immediately after, $50 \mu \mathrm{L}$ of a solution of both chlorophenol red- $\beta$-D-galactopyranoside $(\mathrm{CPRG})$ and cyclohexamide was added into each well. The cyclohexamide was used to terminate the protein synthesis and to allow for an end-point measurement of $\beta$-galactosidase generated by the yeast during the exposure period before introduction of the CPRG (De Boever et al., 2001). The CPRGcyclohexamide solution was prepared by addition of $200 \mu \mathrm{L}$ of CPRG stock solution $\left(10 \mathrm{mg} \mathrm{mL}^{-1}\right.$ minimal growth me- dium) and $1 \mathrm{~mL}$ cyclohexamide stock solution $\left(20 \mathrm{mg} \mathrm{mL}^{-1}\right.$ ethanol) to $4 \mathrm{~mL}$ minimal growth medium. Final concentration of cyclohexamide in the wells was about $1000 \mathrm{mg} \mathrm{L}^{-1}$. The multiwell plates were then incubated at $37^{\circ} \mathrm{C}$ to enable rapid development of the red color, indicating the presence of estrogenic activity. The red color development and density of the yeast cells in each well were read at 540 and $630 \mathrm{~nm}$, respectively, with a Biokinetic multi-well reader (Labsystems BV, Brussels, Belgium).

\section{Calculation of the 17- $\alpha$-Ethinylestradiol Equivalent}

The $\beta$-galactosidase intensity was quantified by dividing the absorbance of the red color of the CPRG metabolite at $540 \mathrm{~nm}$ by that of yeast growth at $630 \mathrm{~nm}$. Background interference was avoided by subtracting the ratio of absorbance at $540 \mathrm{~nm}$ to that at $630 \mathrm{~nm}$ of the negative control from the other values. The corrected value for $\beta$-galactosidase intensity evoked by a concentration of $2964 \mathrm{ng} \mathrm{L}^{-1}$ of EE2 was considered equal to $100 \%$ estrogenic activity response and the percentage of the mean maximum estrogenic response at $X$ concentration of EE2 in the wells was computed as follows:

$\%$ mean maximum response

$$
=\frac{100 \% \times\left[\frac{A_{540}}{A_{630}}(X)-\frac{A_{540}}{A_{630}}(\text { blank })\right]}{\left[\frac{A_{540}}{A_{630}}\left(2964 \mathrm{ng} \mathrm{L}^{-1}\right)-\frac{A_{540}}{A_{630}}(\text { blank })\right]}
$$

The dose response curve was generated with a four-parameter logistic model based on the Marquardt-Levenberg algorithm (Sigmaplot 4.0; SPSS, 1997) (De Boever et al., 2001).

$$
Y=\min +\frac{\max -\min }{1+10^{\left(\operatorname{LogEC}_{50}-X\right) \text { hillslope }}}
$$

where $Y$ is the percent mean maximum response, $X$ is the EE2 concentration, $\max$ is the plateau of the curve, min is the baseline, EC50 is the transition center or the potency (i.e., the EE2 concentration that evokes a $50 \%$ estrogenic activity response), and hillslope is the slope of the curve at the transition center.

The logistic model parameters obtained from the standard dose response curve with EE2 dissolved in DMSO and the net response obtained with each Soxhlet extract were fitted in the four-parameter equation to calculate the equivalent EE2 concentrations in $\mathrm{ng} \mathrm{L}^{-1}$. For the calculations of EE2 equivalent concentrations in the flue gas matrices, the total volume of the Soxhlet extracts and the flue gas sample volumes were taken into account.

\section{Analyses for Polycyclic Aromatic Hydrocarbons}

Analysis of the PAH content in the Soxhlet extracts was performed by gas chromatography coupled with mass spectrometry (GC-MS). The MS detector used was a quadropole mass spectrometer (Trace-MS; Fisons/Thermoquest-Interscience, Belgium). The detection was performed in full scan electron impact mode. Masses with $\mathrm{m} / \mathrm{z}$ from 60 to 400 were scanned in $0.4 \mathrm{~s}$. Transfer line and the ion source were held at 300 and $250^{\circ} \mathrm{C}$, respectively. A DB5ms capillary column $(60 \mathrm{~m} \times 0.25 \mathrm{~mm} \times 0.25 \mu \mathrm{m} ; \mathrm{J} \& \mathrm{~W}$ Scientific, Folsom, CA $)$ fitted with a retention gap (deactivated fused silica) was used for the chromatographical separations. The column was mounted in a Trace-GC (Fisons/Thermoquest-Interscience) on an oncolumn injector. Injections $(1 \mu \mathrm{L})$ were performed with an AS800 autosampler (Fisons/Thermoquest-Interscience). After injection the oven temperature was maintained at $55^{\circ} \mathrm{C}$ for 
$1 \mathrm{~min}$, then programmed to $140^{\circ} \mathrm{C}$ at $12^{\circ} \mathrm{C} \mathrm{min}{ }^{-1}$, followed by a second ramp of $5^{\circ} \mathrm{C} \mathrm{min}^{-1}$ to $300^{\circ} \mathrm{C}$. This temperature was held for $15 \mathrm{~min}$. Helium was used as carrier gas, and kept at $0.8 \mathrm{~mL} \mathrm{m^{-1 }}$ (constant flow mode). Data were recorded with Xcalibur software (Thermo Finnigan, 1998). The variability of all measurement was $0.1 \%$, unless otherwise stated.

\section{RESULTS}

Figure 1 shows the calibration curve for the yeast estrogen screen bioassay obtained with standard concentrations of the model compound (EE2) in DMSO at $2 \%$. The effective concentration of EE2 capable of causing a $50 \%$ of the maximum mean estrogenic response (EC50) was found to be $200 \pm 25 \mathrm{ng} \mathrm{L}^{-1}$ and the upper and the lower detection limits for the estrogen screen bioassay were about 2950 and $5.8 \mathrm{ng} \mathrm{L}^{-1}$, respectively.

The combustion of nontreated wood samples, wood samples treated with copper naphthenate, and barbecue charcoal consistently had detectable estrogenic activity (Fig. 2A). Combustion of wood alone released the largest amount of EE2 ranging from 27 to $234 \mathrm{ng} \mathrm{m}^{-3}$. Flue gases produced from combustion of wood treated with the copper naphthenate and barbecue charcoal contained EE2 concentrations of 15 to 180 and 27 to $81 \mathrm{ng}$ $\mathrm{m}^{-3}$, respectively. The Soxhlet extracts of flue gases produced from combustion of wood treated with both copper naphthenate and pentachlorophenol, kitchen waste, or meat were largely toxic to the yeast as indicated by low absorbance at both the of 540 and $630 \mathrm{~nm}$ wavelength (results not shown). As such, the estrogenic activ-

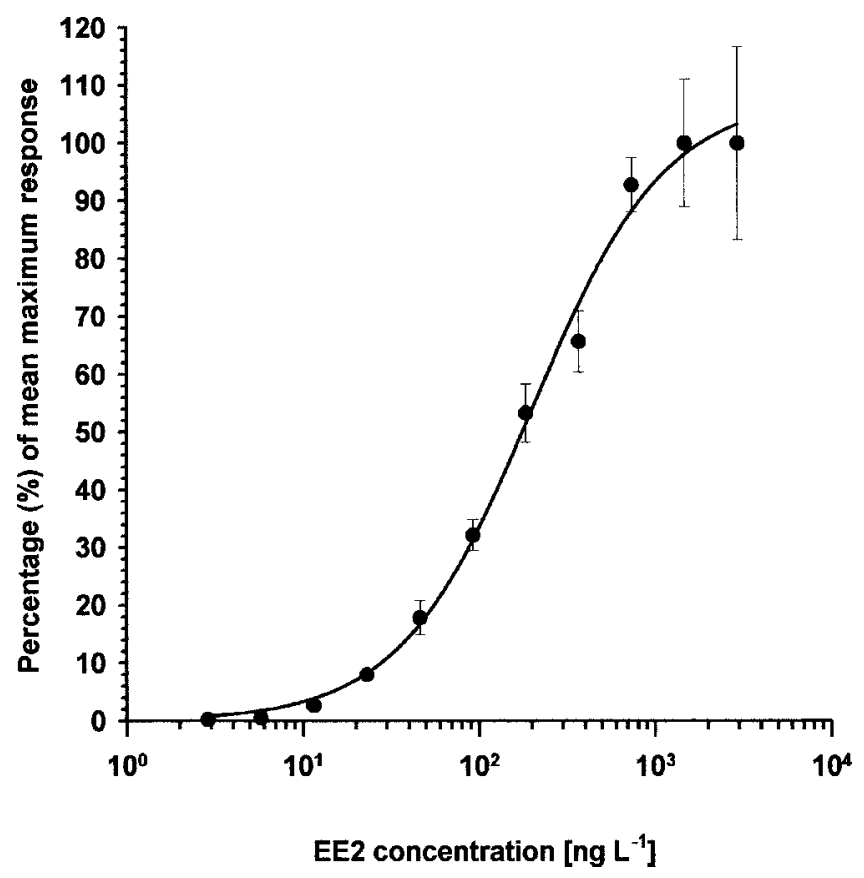

Fig. 1. Dose response curve for the yeast-based human estrogen receptor (hER) assay to synthetic estrogen 17 $\alpha$-ethynylestradiol (EE2) dissolved in dimethylsulfoxide (DMSO) solvent in concentrations of 2.9 to $2950 \mathrm{ng} \mathrm{L}^{-1}$. The response is expressed as a percentage of the mean maximum response elicited by $2950 \mathrm{ng}$ $\mathbf{L}^{-1}$ of $\operatorname{EE2}(n=8)$. Note the EC50 (effective concentration to cause $50 \%$ of the mean maximum estrogenic response) $=200 \pm$ $25 \mathrm{ng} \mathbf{L}^{-1}$. ity for these flue gas streams could not be determined reliably. Figure $2 \mathrm{~B}$ shows the total concentration of the 16 USEPA standard PAHs $\left(\mathrm{ng} \mathrm{m}^{-3}\right)$ in flue gas streams from combustion of different materials and the replicates. With the exception of barbecue charcoal, other samples that were combusted resulted in formation of flue gas streams with total concentration of the 16 PAHs varying from 7000 to $632000 \mathrm{ng} \mathrm{m}^{-3}$. Flue gas from combustion of barbecue charcoal contained 110 to 301 $n g \mathrm{~m}^{-3}$ PAHs. Figure 3 shows a scatter diagram of the concentration of EE2 equivalent against that of total $\mathrm{PAHs}$ in the flue gas matrices from combustion of all the different samples and the replicates. There is no evidence of a relationship between the concentration of PAHs and the estrogenic activity. Table 1 shows the average values of EE2 equivalents and PAHs contained in the flue gas streams and the temperature in the primary and the secondary combustion chambers. Results
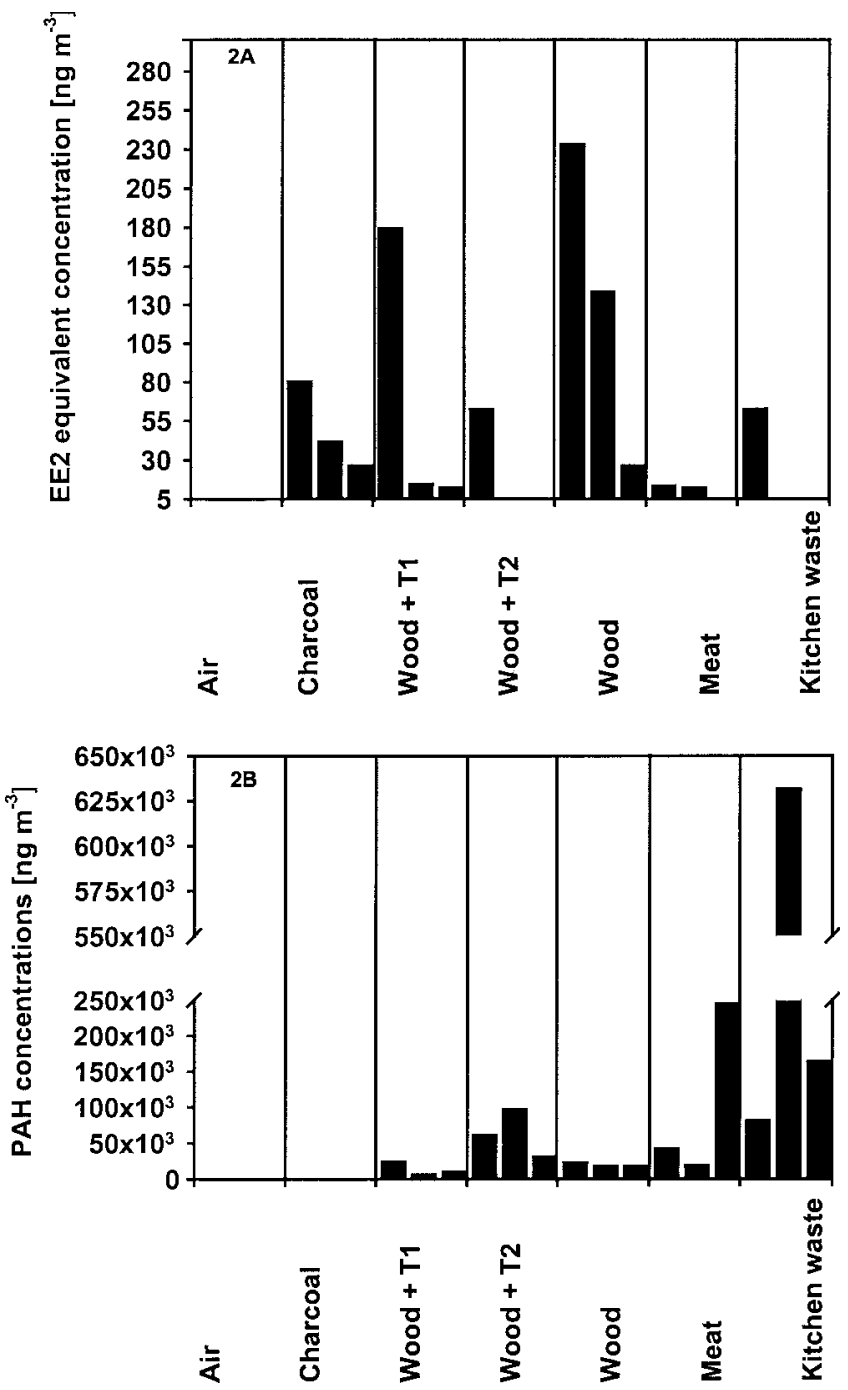

Fig. 2. Concentration of $(A)$ estrogenic compounds expressed as 17- $\alpha$ ethinylestradiol (EE2) equivalent $\left(\mathrm{ng} \mathrm{m}^{-3}\right)$ and $(B)$ total concentration of the 16 USEPA standard polycyclic aromatic hydrocarbons (PAHs) $\left(\mathrm{ng} \mathrm{m}^{-3}\right)$ in flue gas streams from combustion of different materials and the replicates. T1, treatment with copper naphthenate wood preservative; $T 2$, treatment with copper naphthenate and pentachlorophenol wood preservative. 


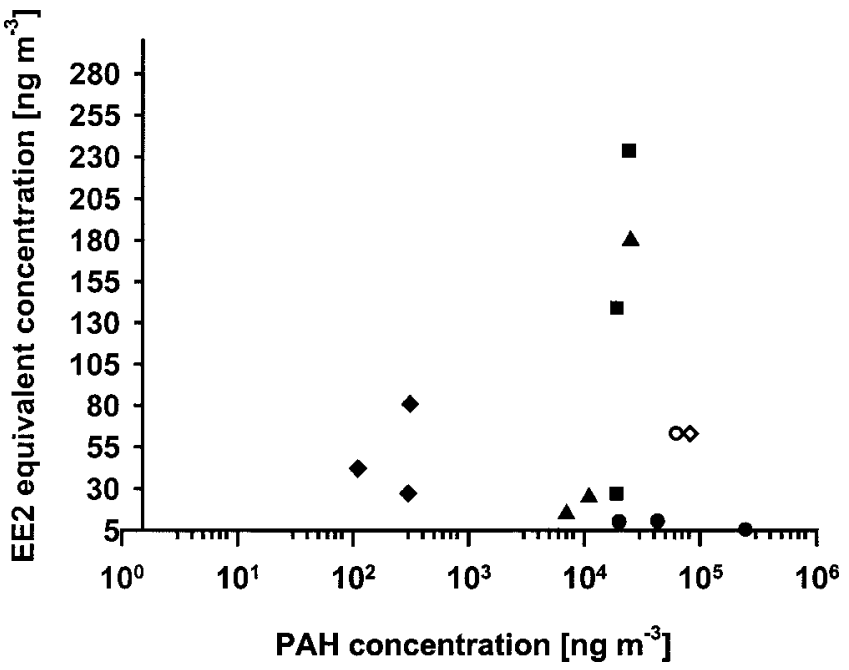

Fig. 3. A scatter diagram showing the 17- $\alpha$-ethinylestradiol (EE2) equivalent concentration $\left(\mathrm{ng} \mathrm{m}^{-3}\right)$ against the total concentration of the 16 USEPA standard polycyclic aromatic hydrocarbons (PAHs) (ng $\mathrm{m}^{-3}$ ) in flue gases from combustion of different material samples and their replicates. $\bullet$, Barbecue charcoal; $\Delta$, wood treated with copper naphthenate wood preservative; $\bigcirc$, wood treated with copper naphthenate combined with pentachlorophenol wood preservatives; $\square$, untreated wood; $\bigcirc$, meat; $\diamond$, kitchen waste.

demonstrate large variability in the concentration of EE2 equivalents and that of the 16 PAHs. The combustion of kitchen waste or meat in particular yielded flue gas streams containing relatively large amounts of PAHs and little or no EE2 equivalent. As expected, the flue gases obtained by drawing ambient air through the empty oven had no detectable estrogenic activity or PAHs.

\section{DISCUSSION}

An effective concentration of EE2 capable of causing $50 \%$ of the mean maximum estrogenic activity (EC50) of $200 \pm 25 \mathrm{ng} \mathrm{L}^{-1}$ obtained in this study is comparable with a reported value of $237 \mathrm{ng} \mathrm{L}^{-1}$ (Gaido et al., 1997). $17-\alpha$-Ethinylestradiol was used as a model estrogenic compound due to its reputation as an environmental estrogen (Kozak et al., 2001). There were large differences in the magnitude of estrogenic compounds and PAHs in all the flue gas streams from the materials tested, and the estrogenic compounds emitted in the flue gas streams were not closely related with the level of PAHs. On the other hand, the absence of PAHs did not imply the absence of estrogenic compounds. The formation of organic micropollutants in closed combustion equipment is a function of temperature, aeration, flaming intensity, and the extent of solid-phase combustion (Cooper, 1980). In this study, the combustion temperature, aeration, and flaming intensity were not strictly controlled and the temperatures in both combustion chambers were chosen to approximate scenarios in uncontrolled burning of wood, charcoal, dead animal carcasses, and backyard waste.

This study shows that burning processes such as those that occur in residential wood stoves and fireplaces and during burning of backyard waste or animal carcasses may be a significant source of estrogenic compounds in the environment. Estrogenic compounds are typically active at low concentrations (Miyamoto and Klein, 1998). However, most studies on hazards related to combustion processes are concerned with the formation of volatile organic compounds, PAHs, polychlorinated biphenyls (PCBs), polychlorinated dibenzo dioxins (PCDDs), and polychlorinated dibenzo furans (PCDFs) due to their established carcinogenic properties at ubiquitous amounts in the environment (Till et al., 1997; Kjallstrand et al., 2000). Indeed, regulatory limits for emissions of PAHs, PCDDs, PCDFs, and volatile organic compounds such as benzene from combustion installations exist for most

Table 1. The average values of $17-\alpha$-ethinylestradiol (EE2) equivalents and polycyclic aromatic hydrocarbons (PAHs) contained in the flue gas streams for different material samples and the replicates that were combusted in relation to the temperature in the primary and secondary combustion chambers. The number of replicates each sample is analyzed for estrogenic activity $(n)=8$.

\begin{tabular}{|c|c|c|c|c|}
\hline \multirow[t]{2}{*}{ Sample description } & EE2 equivalent of flue gas & 16 PAHs in the flue gas & \multicolumn{2}{|c|}{$\begin{array}{l}\text { Temperature in the } \\
\text { combustion } \\
\text { chambersPrimary } \\
\text { Sec- } \\
\text { ondary }\end{array}$} \\
\hline & ng $\mathbf{m}^{-3}$ & $10^{3} \mathrm{ng} \mathrm{m}^{-3}$ & 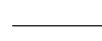 & 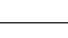 \\
\hline \multirow[t]{3}{*}{ Air } & BDL $\dagger$ & BDL & 1000 & 162 \\
\hline & BDL & BDL & 1000 & 106 \\
\hline & BDL & BDL & 1000 & 170 \\
\hline \multirow{3}{*}{ Nontreated wood } & $27 \pm 3$ & 19 & 1000 & 320 \\
\hline & $139 \pm 7$ & 19 & 1000 & 170 \\
\hline & $234 \pm 25$ & 24 & 1000 & 200 \\
\hline \multirow[t]{3}{*}{ Wood treated with copper naphthenate } & $180 \pm 19$ & 25 & 1000 & 230 \\
\hline & $15 \pm 26$ & 7 & 1000 & 140 \\
\hline & $25 \pm 8$ & 11 & 1000 & 190 \\
\hline \multirow{3}{*}{$\begin{array}{l}\text { Wood treated with copper naphthenate + pentachloro- } \\
\text { phenol }\end{array}$} & BDL & 32 & 1000 & 250 \\
\hline & $63 \pm 47$ & 62 & 1000 & 300 \\
\hline & BDL & 98 & 1000 & 300 \\
\hline \multirow{3}{*}{ Barbecue charcoal } & $27 \pm 15$ & 0.3 & 1000 & 200 \\
\hline & $42 \pm 23$ & 0.11 & 1000 & 211 \\
\hline & $81 \pm 22$ & 0.31 & 1000 & 100 \\
\hline \multirow[t]{3}{*}{ Meat } & BDL & 246 & 965 & 151 \\
\hline & $13 \pm 13$ & 20 & 1000 & 211 \\
\hline & $14 \pm 16$ & 43 & 935 & 126 \\
\hline \multirow[t]{3}{*}{ Kitchen waste } & BDL & 165 & 900 & 225 \\
\hline & BDL & 632 & 850 & 178 \\
\hline & $63 \pm 21$ & 82 & 925 & 184 \\
\hline
\end{tabular}

\footnotetext{
$\dagger$ Below detection limit.
} 
countries in the European Union and other developed countries (Ulrich and Broker, 1997). To the best of our knowledge, there is no evidence so far on the emission and propagation of estrogenic compounds in the atmosphere or on their fate in the biosphere. Moreover, bioaccumulation of compounds exhibiting estrogenic activity in the food chain cannot be ruled out. Therefore, practical implications of discharging flue gas streams from combustion of wood chips as such and barbecue charcoal with estrogenic compounds at concentrations of 27 to 234 and 27 to $81 \mathrm{ng} \mathrm{m}^{-3}$, respectively, require further investigation.

In some cases, the solvent extracts of these flue gases were toxic to the yeast strain. While no additional tests were performed to establish the exact cause of the toxic effect, the results do highlight the limitations of the yeast estrogen screen bioassay to assess whole-solvent extracts of flue gas streams for estrogenic activity. However, the yeast estrogen screen bioassay is more resistant to environment-related toxicity compared with other known estrogen screen bioassays (Routledge and Sumpter, 1996; Zacharewski, 1997). Some polychlorinated biphenyl congeners were shown to have an estrogenic activity (Soto et al., 1995; Shelby et al., 1996; Gaido et al., 1997). Polychlorinated dibenzo dioxins have also been identified as a possible group of compounds with estrogenic activity (Ternes, 1998). However, the likely presence of these organic micropollutants in the entire flue gas matrices (though not established) did not lead to higher levels of estrogenic activity and neither to a strong increase in the PAH concentrations under the conditions of the tests. A major aspect to consider in this respect is the sorption efficiency of the polyurethane foam. Indeed, in a previous study (Muthumbi et al., 2002), the flue gases were scrubbed by means of methylene chloride solvent. Such an approach, although limited to small volumes of flue gas samples, yielded stronger signals of estrogenic activity. The influence of the sorption matrices and scrubbing solvents on the removal of estrogenic pollutants from gaseous matrices therefore deserves further exploration.

\section{CONCLUSIONS}

The results of this study illustrate that flue gas emissions from combustion processes present a source of estrogenic compounds in the environment. However, the magnitude of estrogenic compounds in the flue gas matrices from the combustion of wood, charcoal, meat, and kitchen waste does not appear to be directly related to the total concentration of PAHs. These findings warrant further research on the emission and propagation of substances with estrogenic activity in the environment from combustion processes.

\section{ACKNOWLEDGMENTS}

We acknowledge the assistance we received from the Laboratory of Wood Technology at Ghent University in the preparation of wood samples. We would also like to thank Joris Roels for useful discussions on the experimental design. We thank Greet Van De Velde for maintaining the recombinant yeast culture. We are grateful to Jef Vandenberghe for technical assistance. This project is supported by the Fund for Scientific Research, Flanders, Belgium (Grant no. G.0102.00N).

\section{REFERENCES}

Arnold, S.F., M.K. Robinson, A.C. Notides, L.J. Guillette, and J.A McLachlan. 1996. A yeast estrogen screen for examining the relative exposure of cells to natural and xenoestrogens. Environ. Health Perspect. 104:544-548.

Charles, G.D., M.J. Bartels, T.R. Zacharewski, B.B. Gollapudi, N.L. Freshour, and E.W. Carney. 2000. Activity of benzo[a]pyrene and its hydroxylated metabolites in an estrogen receptor-alpha reporter gene assay. Toxicol. Sci. 55:320-326.

Clemons, J.H., L.M. Allan, C.H. Marvin, Z. Wu, B.E. McCarry, D.W. Bryant, and T.R. Zacharewski. 1998. Evidence of estrogen- and TCDD-like activities in crude and fractionated extracts of PM10 air particulate material using in vitro gene expression assays. Environ. Sci. Technol. 32:1853-1860.

Cooper, J.A. 1980. Environmental impact of residential wood combustion emissions and its implications. J. Air Pollut. Control Assoc. 30:855-861.

Davies, I.W., R.M. Harrison, R. Perry, D. Ratnayaka, and R.A. Wellings. 1976. Municipal incinerator as source of polynuclear aromatic hydrocarbons in environment. Environ. Sci. Technol. 10:451-453.

De Boever, P., W. Demare, E. Vanderperren, K. Cooreman, P. Bossier, and W. Verstraete. 2001. Optimization of a yeast estrogen screen and its applicability to study the release of estrogenic isoflavones from a soygerm powder. Environ. Health Perspect. 109: 691-697.

Gaido, K.W., L.S. Leonard, S. Lovell, J.C. Gould, D. Babai, C.J. Portier, and D.P. McDonnell. 1997. Evaluation of chemicals with endocrine modulating activity in a yeast-based steroid hormone receptor gene transcription assay. Toxicol. Appl. Pharmacol. 143: 205-212.

Gillesby, B.E., and T.R. Zacharewski. 1998. Exoestrogens: Mechanisms of action and strategies for identification and assessment Environ. Toxicol. Chem. 17:3-14.

Guillette, L.J., T.S. Gross, G.R. Masson, J.M. Matter, H.F. Percival, and A.R. Woodward. 1994. Developmental abnormalities of the gonad and abnormal sex-Hormone concentrations in juvenile alligators from contaminated and control lakes in florida. Environ. Health Perspect. 102:680-688

Guillette, L.J., D.B. Pickford, D.A. Crain, A.A. Rooney, and H.F Percival. 1996. Reduction in penis size and plasma testosterone concentrations in juvenile alligators living in a contaminated environment. Gen. Comp. Endocrinol. 101:32-42.

Gullett, B.K., P.M. Lemieux, C.C. Lutes, C.K. Winterrowd, and D.L. Winters. 2001. Emissions of PCDD/F from uncontrolled, domestic waste burning. Chemosphere 43:721-725.

Gullett, B.K., A. Touati, and C.W. Lee. 2000. Formation of chlorinated dioxins and furans in a hazardous-waste-firing industrial boiler. Environ. Sci. Technol. 34:2069-2074.

Katzenellenbogen, J.A. 1995. The structural pervasiveness of estrogenic activity. Environ. Health Perspect. 103:99-101.

Kjallstrand, J., O. Ramnas, and G. Petersson. 2000. Methoxyphenols from burning of Scandinavian forest plant materials. Chemosphere 41:735-741.

Kozak, R., I. D'Haese, and W. Verstraete. 2001. Focus on the 17-alphaethinylestradiol. p. 265. In K. Kummerer (ed.) Pharmaceuticals in the environment. Springer-Verlag, Heidelberg, Germany.

Launhardt, T., and H. Thoma. 2000. Investigation on organic pollutants from a domestic heating system using solid biofuels. Chemosphere 40:1149-1157.

McCready, S., D.J. Slee, G.F. Birch, and S.E. Taylor. 2000. The distribution of polycyclic aromatic hydrocarbons in surficial sediments of Sydney Harbour, Australia. Mar. Pollut. Bull. 40:999-1006.

McLachlan, J.A., R.R. Newbold, H.C. Shah, M.D. Hogan, and R.L. Dixon. 1982. Reduced fertility in female mice exposed transplacentally to diethylstilbestrol (DES). Fertil. Steril. 38:364-371.

Miyamoto, J., and W. Klein. 1998. Environmental exposure, species differences and risk assessment. In Natural and anthropogenic environmental oestrogens: The scientific basis for risk assessment. Pure \& Appl. Chem. 70:1829-1845. 
Muthumbi, W., P. De Boever, I. D'Haese, W. D'Hooge, E.M. Top, J.G. Pieters, F. Comhaire, and W. Vestraete. 2002. Assessment of estrogenic activity of flue gases from burning processes by means of the yeast based human estrogen receptor (hER) bioassay. Environ. Technol. 23:287-291.

Obernberger, I. 1998. Decentralized biomass combustion: State of the art and future development. Biomass Bioenergy 14:33-56.

Pimenta, A.S., J.M. Bayona, M.T. Garcia, and A.M. Solanas. 2000. Evaluation of acute toxicity and genotoxicity of liquid products from pyrolysis of Eucalyptus grandis wood. Arch. Environ. Contam. Toxicol. 38:169-175.

Routledge, E.J., and J.P. Sumpter. 1996. Estrogenic activity of surfactants and some of their degradation products assessed using a recombinant yeast screen. Environ. Toxicol. Chem. 15:241-248.

Shelby, M.D., R.R. Newbold, D.B. Tully, K. Chae, and V.L. Davis. 1996. Assessing environmental chemicals for estrogenicity using a combination of in vitro and in vivo assays. Environ. Health Perspect. 104:1296-1300.

Simoneit, B.R.T., W.F. Rogge, Q. Lang, and R. Jaffe. 2001. Molecular characterization of smoke from campfire burning of pine wood (Pinus elliottii). Chemosphere 2:107-122.
Soto, A.M., C. Sonnenschein, K.L. Chung, M.F. Fernandez, N. Olea, and F.O. Serrano. 1995. The E-screen assay as a tool to identify estrogens-An update on estrogenic environmental pollutants. Environ. Health Perspect. 103:113-122.

SPSS. 1997. Sigmaplot 4.0. SPSS, Chicago, IL.

Stieglitz, L., and H. Vogg. 1987. On formation conditions of PCDD and PCDF in fly-ash from municipal waste incinerators. Chemosphere 16:1917-1922.

Ternes, T.A. 1998. Occurrence of drugs in German sewage treatment plants and rivers. Water Res. 32:3245-3260.

Thermo Finnigan. 1998. Xcalibur Version 1.2. Thermo Finnigan, San Jose, CA

Till, M., P. Behnisch, H. Hagenmaier, K.W. Bock, and D. Schrenk. 1997. Dioxinlike components in incinerator fly ash: A comparison between chemical analysis data and results from a cell culture bioassay. Environ. Health Perspect. 105:1326-1332.

Ulrich, Q., and G. Broker. 1997. Identification of relevant industrial sources of dioxins and furans in Europe. The European Dioxin Inventory Final Rep. 43. North Rhine-Westphalia State Environ. Agency, Essen, Germany.

Zacharewski, T. 1997. In vitro bioassays for assessing estrogenic substances. Environ. Sci. Technol. 31:613-623. 